\title{
Climate Change Impact on Soil Moisture Variability: Health Effects of Radon Flux Density Within Ogbomoso, Nigeria
}

\author{
Olukunle Olaonipekun Oladapo, Leonard Kofitse Amekudzi, \\ Olatunde Micheal Oni, Abraham Adewale Aremu, and \\ Marian Amoakowaah Osei
}

\section{Contents}

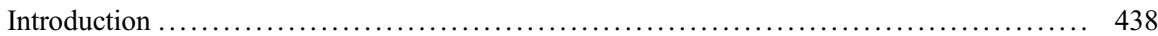

Climate Change and Soil Moisture ........................................ 439

Radon and Human Health ............................................... 440

Silmulation and Forecasting of Soil Moisture Within Ogbomoso Using the Swat

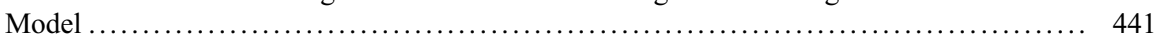

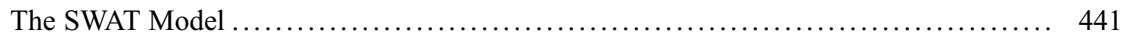

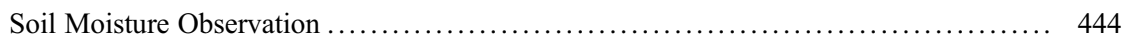

Soil Moisture Simulation ............................................. 445

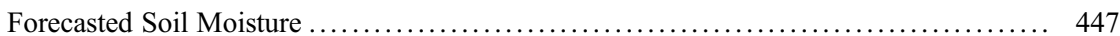

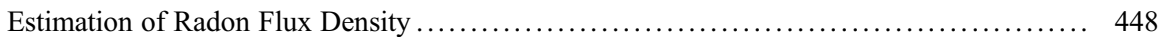

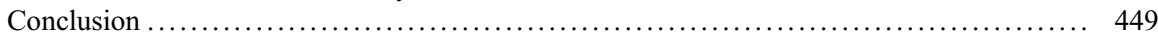

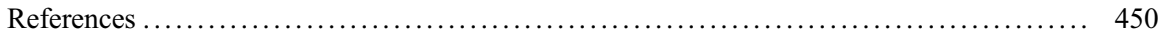

This chapter was previously published non-open access with exclusive rights reserved by the Publisher. It has been changed retrospectively to open access under a CC BY 4.0 license and the copyright holder is "The Author(s)". For further details, please see the license information at the end of the chapter.

O. O. Oladapo $(\bowtie)$

Department of Science Laboratory Technology, Ladoke Akintola University of Technology, Ogbomoso, Nigeria

e-mail: oooladapo66@lautech.edu.ng

L. K. Amekudzi · M. A. Osei

Department of Physics, Kwame Nkrumah University of Science and Technology, Kumasi, Ghana

O. M. Oni

Department of Pure and Applied Physics, Ladoke Akintola University of Technology, Ogbomoso, Nigeria

e-mail: omoni@lautech.edu.ng
A. A. Aremu
Department of Physics with Electronics, Dominion University, Ibadan, Oyo, Nigeria 


\section{Abstract}

Climate affects the quantity of soil moisture within the surface of the earth and this is obtained by affecting the amount of radon flux density escaping from the land surface. This chapter contains the evaluation of climate change conditions as it affects the variability of soil water for the purpose of estimating the health effects of radon flux density within Ogbomoso metropolis. The simulated soil moisture content around Ogbomoso was done for a period of 34 years using the hydrological model, Soil Water Assessment Tool (SWAT). The calibration and validation of the SWAT model was done using the daily observed soil moisture content. The simulated daily soil moisture within Ogbomoso showed good performance when calibrated and validated. A 20 years prediction of the daily soil moisture content was done using the SWAT model. The estimation of the radon flux density for the study area was obtained using the simulated soil temperature and soil moisture from the SWAT model. In this chapter, the UNSCEAR radon flux formula was used for the radon flux estimate. The result showed that the UNSCEAR radon flux formula performed well in estimating the radon flux density in the study area. The mean value of the radon flux density of $15.09 \mathrm{mBqm}^{-2} \mathrm{~s}^{-1}$ falls below the estimated world average of $33 \mathrm{mBqm}^{-2} \mathrm{~s}^{-1}$ by UNSCEAR stipulated for land surface. The results showed that Ogbomoso region is not prone to high risk of radon exposure to the public. The estimation of the radon flux density value suggested that there is no radiological health hazard such as lung cancer or any other respiratory tract diseases to the inhabitant of Ogbomoso, Nigeria.

\section{Keywords}

Climate change $\cdot$ Soil moisture $\cdot$ Radon flux density $\cdot$ Estimating $\cdot$ SWAT model $\cdot$ Ogbomoso $\cdot$ Simulating and forecasting

\section{Introduction}

Climate change has been reported to have significant effects on the amount of soil moisture within the land surface (Schery et al. 1989). This is attainable by managing the quantity of radon emanating from the earth. The main hydrology and climate variable that affects the land surface processes is soil moisture (Tanner 1980; Schery et al. 1989). Soil moisture is a major variable for a large number of uses, including numerical weather forecasting, flood prediction, agricultural drought evaluation, water resources management, and health evaluation (Zhang et al. 2008). Despite the principal importance of soil moisture to agricultural performance, crop observation, and yield prediction, soil moisture statistics is not widely obtainable on a territorial scale in Nigeria. Only finite data sets of soil moisture exist in Nigeria because it is a strenuous property to measure. Soil moisture is naturally diverse because of dissimilarity in moisture-holding abilities of the soil at a very small scale 
and topography. The soil moisture is mostly measured by agro-meteorological experimental stations which are very insufficient in Nigeria. The data obtained from these stations are too few to investigate how the atmosphere relates with the land surface because they are measured basically for agriculture. Apart from these, agro-meteorological experimental stations are not available in Ogbomoso metropolis. It is paramount to seek a way to simulate this limited variable.

Investigation has shown that variation in soil moisture have evidential effects on changes in radon concentration (Radon-222) in the atmosphere (Brookins 1990). Radon is a natural radioactive inert gas whose inhalation in excess dose may lead to adverse health effect such as lung cancer. Factors such as climatic parameters, diffusivity, and radon concentration have been identified as some of the factors that determined the concentration of radon in the atmosphere (Zahorowski et al. 2004; Fields 2010). Soil moisture is a major parameter that determines the amount of radon exhalation from the earth surface and radon concentration in the atmosphere (Tanner 1980; Ball et al. 1983; Zhou et al. 2005; Sheffield and Wood 2008). The purpose of this chapter is to assess the health effects of radon flux density due to the impact of climate change on soil moisture within Ogbomoso metropolis, Nigeria. This chapter will provide an all-inclusive, evidence-based, measurable estimation of simulated and forecasted soil moisture for assessing radon flux-related health effect in Ogbomoso, Nigeria.

In this chapter, the simulation and forecasting of the soil moisture from the available meteorological data and other relevant data using the Soil Water Assessment Tool (SWAT) model was investigated to estimate the health effects of radon flux density distribution in the atmosphere. This chapter, therefore, seeks to use the relationship between soil moisture and radon emanation from the ground surface to estimate radon flux density distribution in the atmosphere within Ogbomoso. The objective of this chapter is to investigate the effects of change in climate on the variability of soil moisture for the purpose of estimating radon flux density in the Ogbomoso, Nigeria. The specific objectives of this chapter are to obtain a quantitative estimation of (a) the simulated soil moisture, (b) the forecasted soil moisture, (c) the radon flux density above the land surface, and (d) to investigate the health risk of the estimated radon flux density.

\section{Climate Change and Soil Moisture}

In the interaction of land and the atmosphere, the amount of water in the top soil plays a very principal role (McColl et al. 2017; Koster et al. 2004). Soil moisture is propelled by climate, more significantly by precipitation and temperature (Feng and Liu 2015). Precipitation is the major source of soil moisture, and changes in precipitation will impact the amount of water in the top soil. Furthermore, changes in temperature also affect soil moisture by managing evapotranspiration (Wang et al. 2018a). The application of soil moisture for weather prediction (Alexander 2011; Wang et al. 2018b), drought observation (AghaKouchak 2014), hydrological modeling (Wanders et al. 2014), and vegetation variation (Chen et al. 2014) are gaining 
wide application in recent time. The global warming today and movement of the water cycle may cause changes in soil moisture variability (Sheffield and Wood 2008). It has been reported that changing vegetation can also alter the amount of water in the top soil (Sterling et al. 2013). Vegetation variation has been discovered to affect field ability and soil penetration, thus altering soil moisture (Ouyang et al. 2018). These factors, through some complex relationships, alter soil moisture. Climate variation has been discovered to impact soil moisture greatly. The effects of change in climate and change in vegetation have been reported in literatures.

This chapter considers the implications of change in climate on soil moisture for estimating the health effect of radon flux density. The various soil moisture measuring stations, which are few in number, do not consider the different soil types, soil characteristics, land cover and land use, topography, etc. on the soil moisture. The observation of soil moisture is very scarce. Instead of making use of observation that is limited, numerical models have been employed over time to investigate the changes in hydrological processes and soil moisture, which play a key role in this regard. Numerous hydrological models exist today that can be used for the purpose of simulating the hydrological processes of a watershed. Each model possesses its own pros and cons. The purpose to which an investigation is carried out determines the choice of model to be used. This chapter seeks to examine the Soil Water Assessment Tool (SWAT) model (Arnold et al. 1998) which was chosen due to its ability to simulate hydrologic processes. Another strength of the SWAT model is the fact that it takes into consideration the effects of vegetation properties, topography, soil characteristics, and land type and land cover on the hydrological processes of the soil. This is made possible with the aid of a Digital Elevation Model (DEM) with a very high resolution. Over the years, the SWAT model has become accepted on a global scale as a strong modeling tool suitable for simulating watershed hydrology (Gassman et al. 2007). The SWAT has found application in extensive scope of environmental situations, watershed scales, and framework analysis as described by Gassman et al. (2007). In this chapter, some meteorological data collected from NIMET for Ogbomoso metropolis were fed into the SWAT model to simulate and forecast soil moisture over Ogbomoso. The simulated soil moisture data were used to estimate radon flux density, thereby examining the health effect over Ogbomoso region.

\section{Radon and Human Health}

Over the years, radon gas has been studied for two primary purposes. The first purpose is to investigate the extent to which the general public is exposed to it. Secondly, it was studied to detect the various transfer processes in the atmosphere. The breathing in of radon and its momentary progeny account for about half of the effective dose from all natural sources of ionizing radiation. One of the main challenges of radiation protection to the public is the development of lung cancer as a result of inhalation of the progeny of radon (UNSCEAR 1993). Whenever radon is inhaled in high concentration, it usually leads to diverse health implications. 
Atmospheric radon, which is an inert gas with a half-life of 3.82 days, has been identified as detectors for atmospheric transport. It also doubles as indicators for evaluating and simulating environmental activities (Brookins 1990; Iida et al. 1996; Wang et al. 2004, Zahorowski et al. 2004; Ohkura et al. 2009). Radon concentration in soil and radon exhalation from the soil surface depend on many physical characteristics. These characteristics are related to soil parameters, such as radium content and the internal structure of the soil. Other physical parameters include type of the mineralization, soil porosity, grain size of the soil, permeability of the soil, and emanation coefficient (Mazur et al. 1999; Aburnurad and Al Tamimi 2001). The release of radon gas from the soil to the atmosphere is associated with some of the same processes that control the soil/air exchange of important greenhouse gases like $\mathrm{CH}_{4}, \mathrm{CO}_{2}$, and $\mathrm{NO}_{2}$. Radon does not go through complex chemical reactions and its source term is relatively well known $\left({ }^{226} \mathrm{Ra}\right.$ in soil).

Measurement of radon concentration in the atmosphere has been used for the validation climate models. Due to insufficient radon flux density measurement, measurement of atmospheric radon has been employed in the validation radon flux density from the soil (Kritz et al. 1998; Gupta et al. 2004; Zhang et al. 2008). Therefore, statistics on the territorial distribution of ${ }^{222} \mathrm{Rn}$ exhalation from the earth's surface is regarded as useful for recognizing areas with a health risk of high radon exposure to public. This chapter therefore aimed to use the simulated and forecasted soil moisture to estimate the health effects of radon flux density of Ogbomoso metropolis. Studies of the radon flux densities are able to provide information on the interaction of exchange of gases between the soil and the atmosphere for the purpose of estimating pure health implications of the inhalation of these gases.

\section{Silmulation and Forecasting of Soil Moisture Within Ogbomoso Using the Swat Model}

\section{The SWAT Model}

Soil moisture, which is the amount of water in the upper layer of the soil, has been proven to be affected by changes in climatic properties due to alteration in some meteorological parameters such as precipitation, temperature, relative humidity, solar radiation, and wind speed. The alterations in these parameters are employed in the simulation and forecast of the soil moisture over a particular region provided that relevant data for that region are available. The Soil Water Assessment Tool model known as the SWAT model was used for this purpose within Ogbomoso metropolis. Ogbomoso, which is geographically situated within $4^{\circ} 10^{\prime} \mathrm{E}$ to $4^{\circ} 20^{\prime} \mathrm{E}$ longitude and $8^{\circ} 00^{\prime} \mathrm{N}$ to $8^{\circ} 15^{\prime} \mathrm{N}$ latitude, is investigated in this chapter. The area is situated within the crystal-like Vault of Nigeria (MacDonald and Davies 2000). In Ogbomoso, rocks are classified as either quartzites or gneisses (Ajibade et al. 1988). The agricultural watershed considered in this research work where the simulation and forecasting of soil moisture was carried out is situated within Ogbomoso North Local Government Area as shown in Fig. 1 (Adabanija et al. 2014). Simulation of 


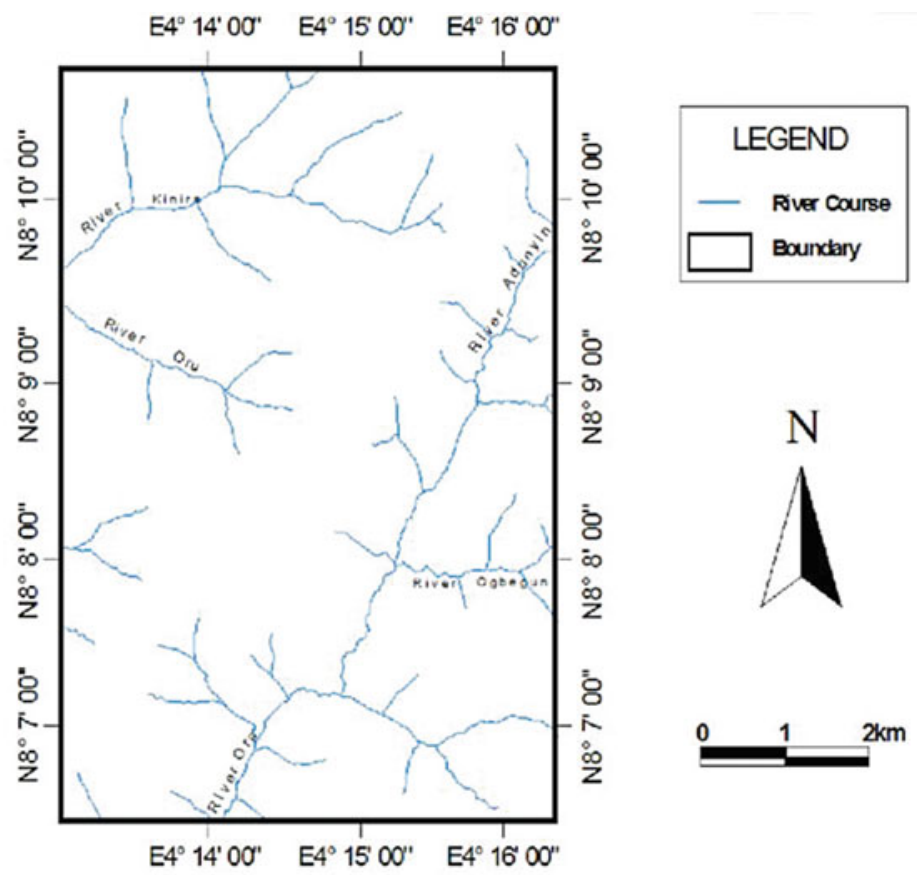

Fig. 1 The map showing the area within the agricultural watershed (Adabanija et al. 2014)

hydrology within this agricultural watershed was considered under diverse topography, vegetation, climatic condition, and soil. The total drainage of the Ogbomoso watershed accounts for a total of $8.58 \mathrm{~km}^{2}$. Ogbomoso, which lies between the savannah and the rain forest, has wet and dry tropical climate. The temperature of the region is fairly uniform throughout the year. It has an average rainfall and temperature of $1200 \mathrm{~mm}$ and $26.20^{\circ} \mathrm{C}$ annually, respectively. The territorial district of Ogbomoso has four seasons similar to other southern Nigeria. The initial raining season in the region starts from April to July characterized by high humidity and heavy rainfall. It is usually interrupted by a short dry period in August before the rainy season resumes again, this time for a short wet season between September and October. The fourth season is the harmattan season which spans between November and ending in the middle of March. The region experiences a relative humidity between $75 \%$ and $95 \%$. Ogbomoso region, being a low land forest, has agricultural activities as major activities of the inhabitants. Figure 1 shows the region of investigation within Ogbomoso metropolis.

"The SWAT has been employed to simulate watersheds globally, it is most frequently chosen due to its vigorous ability to compute the impacts of land management practices on hydrological processes, water quality, and crop growth" (Arnold et al. 1998). In this chapter, the QSWAT, which is a type of the SWAT2012 model, assembled with QGIS 1.4 was employed. The SWAT model operates by breaking a watershed into sub-basins, connected by a stream grid. The Hydrological 
Table 1 Input database and sources for the SWAT model

\begin{tabular}{l|l}
\hline Data Type & Source \\
\hline Digital Elevation Model & SRTM 1-Arc-Second Global v3 (30 m) \\
\hline Land-Use Data & MODIS (15-arc) (Broxton et al. 2014) \\
\hline Soil Data & Digital global soil map FAOv3.6 \\
\hline Meteorological data & Nigerian Meteorological Agency (1984-2017) \\
\hline Climate Projection Data & Canadian Regional Climate Model (2018-2037) \\
\hline
\end{tabular}

Table 2 Statistical model performance for the calibration and validation procedure (Oladapo et al. 2018)

\begin{tabular}{l|l|l|l}
\hline Procedure & $\begin{array}{l}\text { Regression } \\
\text { coefficient }\left(\mathrm{R}^{2}\right)\end{array}$ & $\begin{array}{l}\text { Nash and Sutcliffe } \\
\text { efficiency }\left(\mathrm{E}_{\mathrm{NS}}\right)\end{array}$ & $\begin{array}{l}\text { Percentage } \\
\text { difference }(\mathrm{D})\end{array}$ \\
\hline Calibration & 0.91 & 0.64 & 13 \\
\hline Validation with ESA CCI & 0.81 & 0.53 & 11 \\
\hline $\begin{array}{l}\text { Validation with in situ } \\
\text { measurement }\end{array}$ & 0.88 & 0.84 & 8 \\
\hline Standard & $>0.6$ & $>0.5$ & $\leq 15 \%$ \\
\hline
\end{tabular}

Response Unit (HRU) is the place where the simulation was carried out, which is logged in each basin. The simulated variables (water, sediment, nutrients, and other pollutants) are first simulated at the HRU and then passed through the stream to the water outlet (Arnold et al. 1998; Neitsch et al. 2005). The study on soil moisture simulation and forecasting was first investigated within Ogbomoso by Oladapo et al. (2018) with the aid of climatic data inputs such as precipitation, maximum and minimum temperature, solar radiation, relative humidity, and wind speed. Secondary data of daily precipitation, maximum temperature and minimum temperature data, solar radiation, the humility, and the wind speed were all collected from the Nigerian Meteorological Agency. The data cover between 1979 and 2017. Other data sources including the digital elevation model, land use data, soil data, and climate progression data of the study were used in the simulation and the forecast of the soil moisture in the area (Table 1).

Since Ogbomoso is a natural hydrological setting, five years daily satellite-based soil moisture data (2006-2010) from ESA CCI soil moisture project for the region under investigation were used for the SWAT model calibration. The laid down method of calibration for the SWAT model was carefully followed (Santhi et al. 2001; Neitsch et al. 2005). Due to lack of long-term in situ measurement of soil moisture at the study area, both the short-term in situ measurement of daily soil moisture taken at the study area between April and July 2017 (Oladapo et al. 2018) and five years daily soil moisture data from ESA CCI (2011-2015) were used to validate the SWAT model (Oladapo et al. 2018). Three different model performance statistics were carried out. They are Nash and Sutcliffe efficiency $\left(\mathrm{E}_{\mathrm{NS}}\right)$, percentage difference $(D)$, and the regression coefficient $\left(R^{2}\right)$. A calibration and validation of $\mathrm{E}_{\mathrm{NS}}, \mathrm{D}$, and $\mathrm{R}^{2}$ for hydrology at $\mathrm{E}_{\mathrm{NS}}>0.5, \mathrm{D} \leq 15 \%$, and $\mathrm{R}^{2}>0.6$, respectively, for SWAT model was adopted (Santhi et al. 2001; Moriasi et al. 2007). The three 
statistical model performance used in the calibration and validation procedure for the soil moisture are presented in Table 2.

\section{Soil Moisture Observation}

Five-year satellite-based soil moisture observation data from daily soil moisture data of ESA CCI (2011-2015) and observed soil moisture from the study were obtained. Figure 2 shows the trend in the daily observed soil moisture values during the rainy season (April-July 2017). The highest, lowest, and the mean precipitation are $98.35 \mathrm{~mm}, 1.98 \mathrm{~mm}$, and $48.64 \mathrm{~mm}$, respectively (Oladapo et al. 2018). An increasing precipitation trend was observed from April to July 2017 in the study area. The increasing soil moisture is likely related to the increasing precipitation between April and July which is the rainy season in the study area. This is largely due to reducing temperature during this period. A short variation in daily precipitation was observed in the region as shown in Fig. 3. Model simulated daily soil moisture values from the sub-basin were compared with the daily observed soil

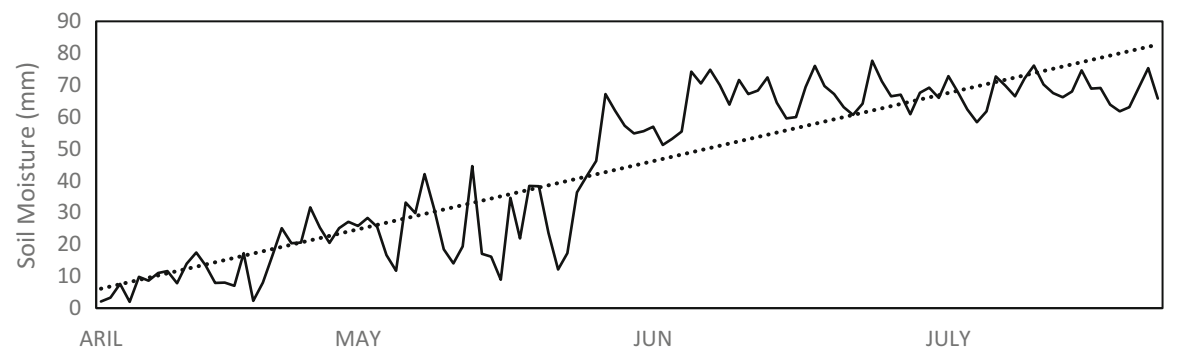

Fig. 2 Trend in the daily soil moisture values observed in 2017 (Oladapo et al. 2018)

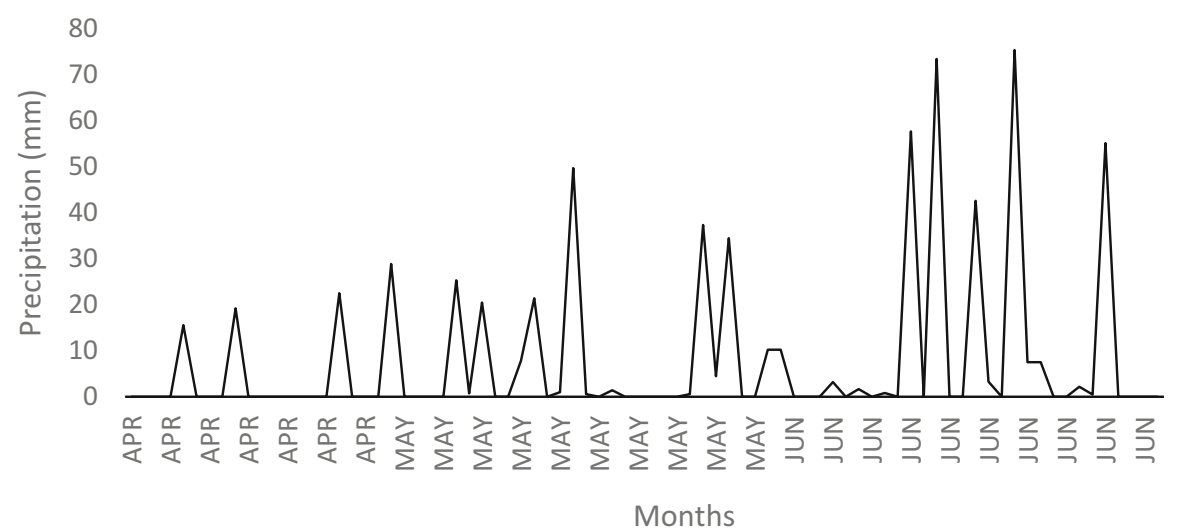

Fig. 3 Precipitation distribution at the watershed during the rainy season in 2017 (Oladapo et al. 2018) 


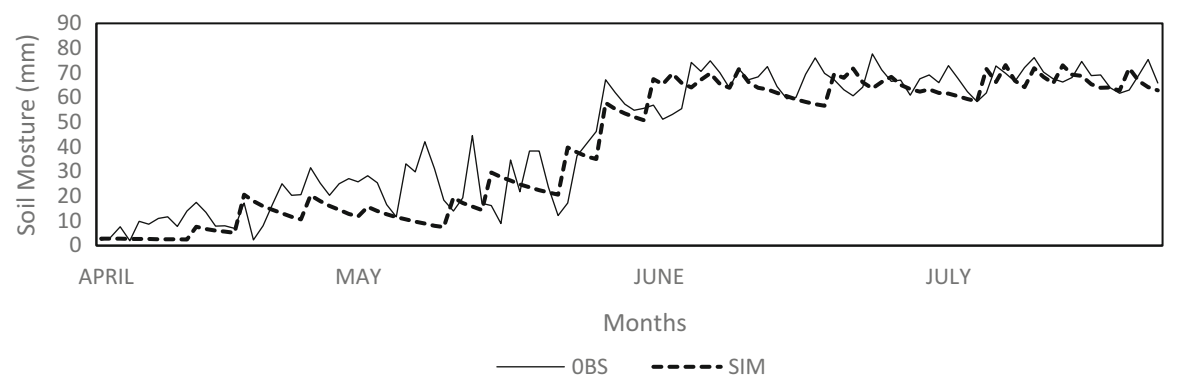

Fig. 4 Comparison between daily means of observations and SWAT simulated soil moisture (April to July 2017) (Oladapo et al. 2018)

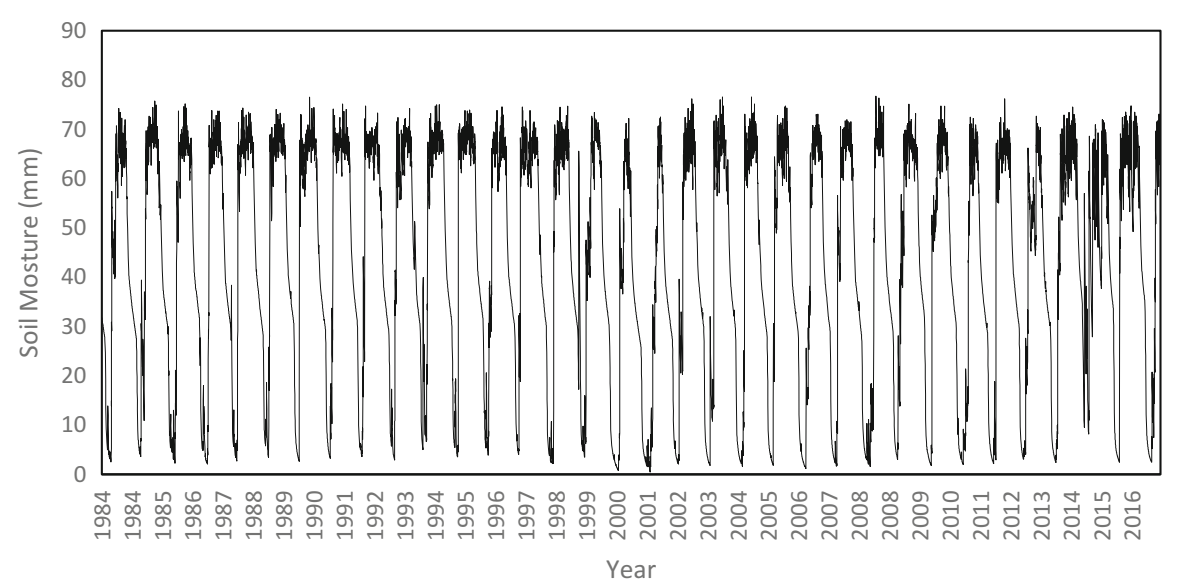

Fig. 5 The 34-year soil moisture simulated by SWAT over Ogbomoso watershed (Oladapo et al. 2018)

moisture values from the field where the sub-basin is located for this four months period. Figure 4 shows that the model closely follows a similar curve to observed value.

\section{Soil Moisture Simulation}

The model simulation allows for a 5-year warm-up period. Therefore, a 5-year secondary climate data inputs obtained from NIMET for Ogbomoso metropolis were used for this purpose. The SWAT was used to simulate the soil moisture in the Ogbomoso watershed for 34-year period (1984-2017). Figure 5 shows the temporal variations of soil moisture in the sub-basin of Ogbomoso watershed over the last 34 years. For the 34-year period, the simulated soil moisture declines slightly. 


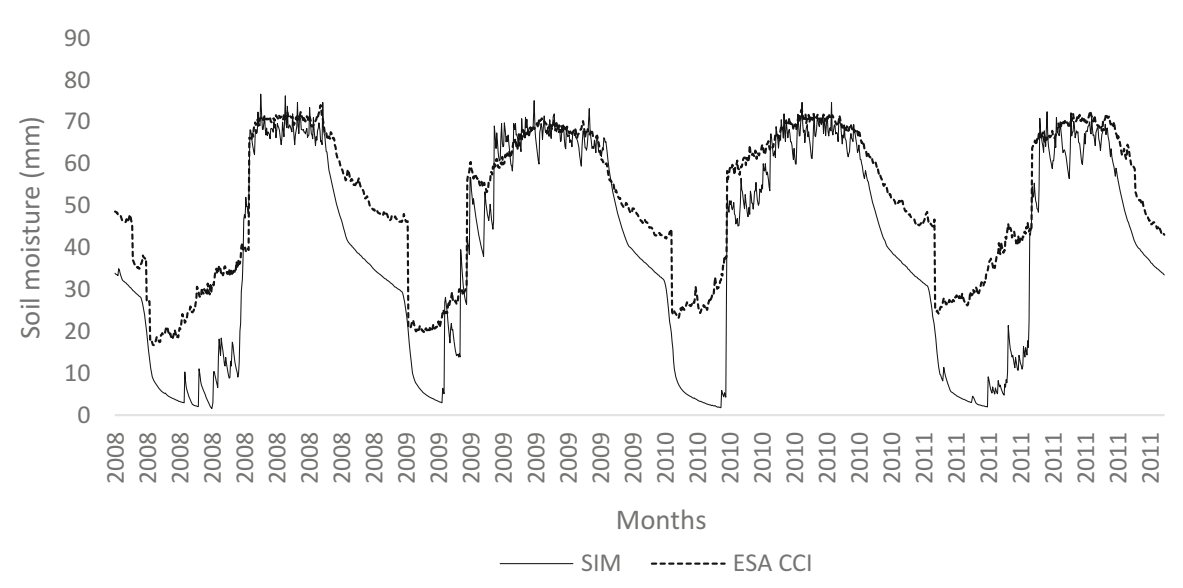

Fig. 6 Comparisons between daily means of SWAT simulated and ESA CCI soil moistures from January to December between 2008 and 2011 (Oladapo et al. 2018)

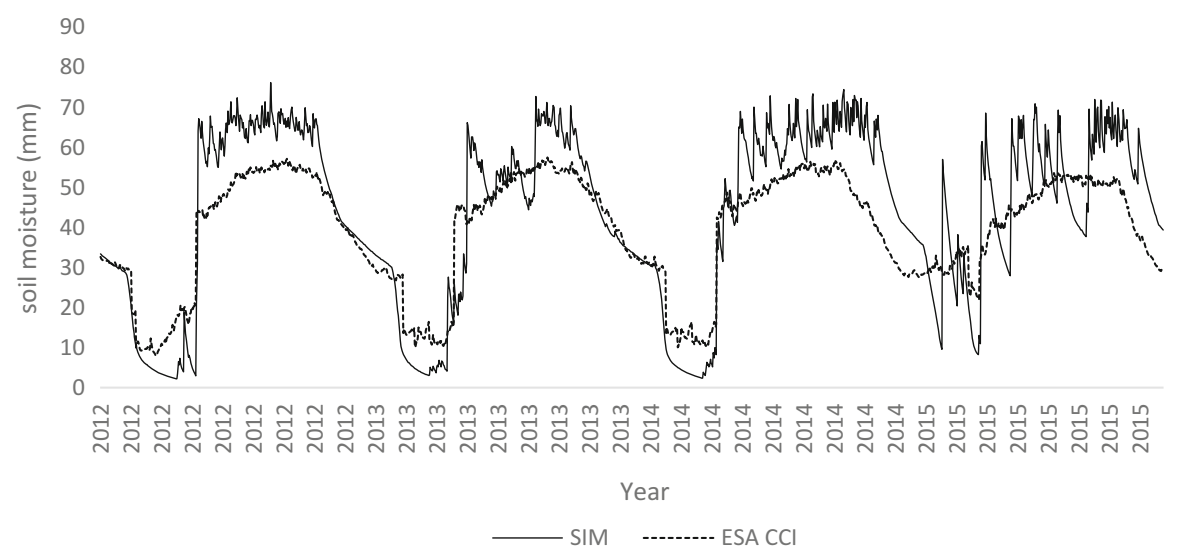

Fig. 7 Comparisons between daily means of SWAT simulated and ESA CCI soil moistures from January to December between 2012 and 2015 (Oladapo et al. 2018)

Figure 6 shows the calibration of the simulated soil moisture with the daily satellite-based soil moisture. There was a good correlation between them. The comparison showed a similar pattern when four years (2012-2015) daily simulated soil moisture from the sub-basin was used for validation as shown in Fig. 7.

The noticeable variation between the daily simulated soil moisture and the satellite-based values of ESA CCI in Figs. 6 and 7 could be traced to the physical and hydraulic parameters associated with the soils, such as soil texture and rainfall, and land cover and land management practices in place. Furthermore, the seasonal variations of the SWAT simulated soil moisture for years 1984, 2000, and 2016 were compared as shown in Fig. 8. Seasonal variations investigated for three years at random showed a similar pattern for the years 1984, 2000, and 2016. The soil 


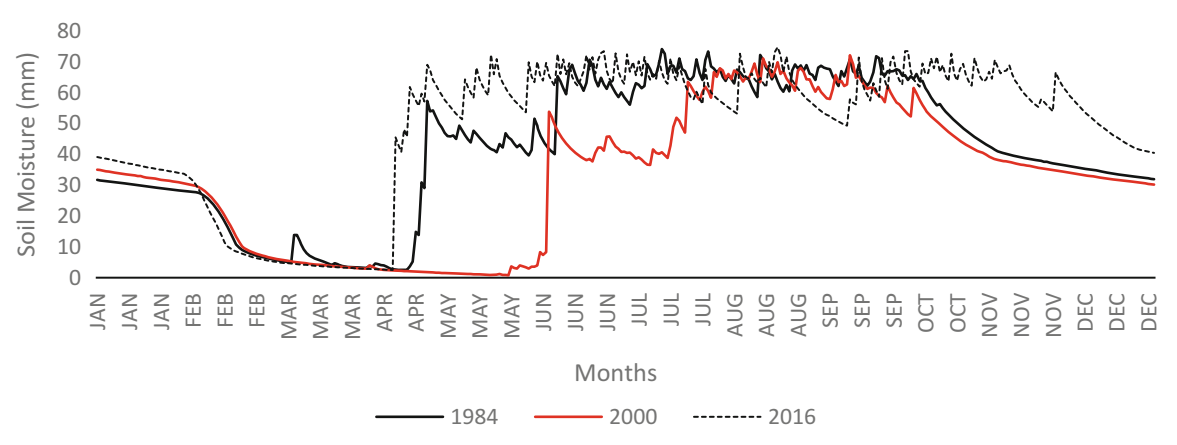

Fig. 8 Seasonal variation of the simulated soil moisture from January to December for year 1984, 2000 and 2016

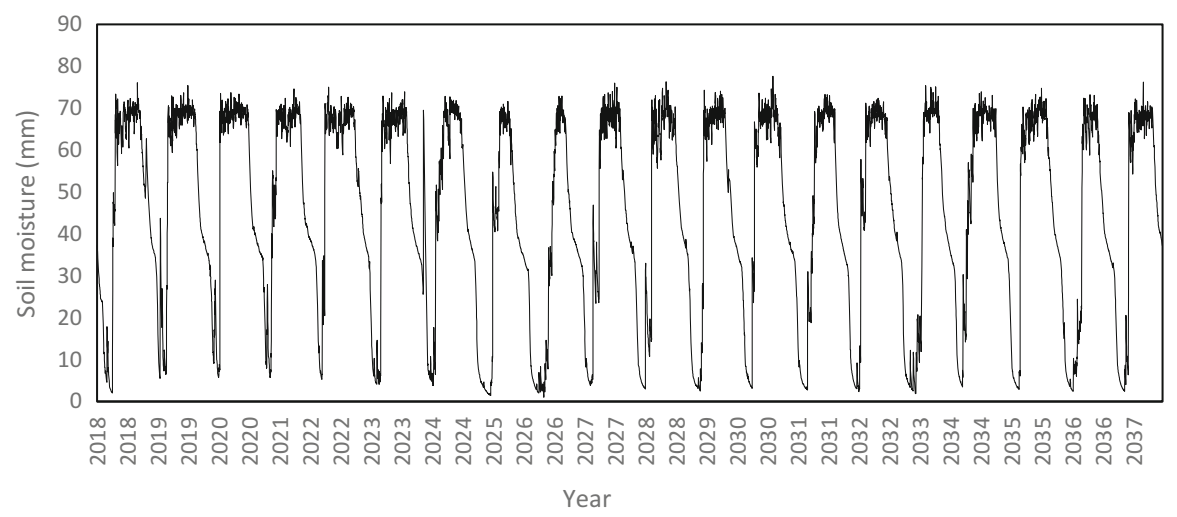

Fig. 9 The 20-year soil moisture forecasted by SWAT over the Ogbomoso watershed (Oladapo et al. 2018)

moisture declines greatly from January till March when the onset of rainfall begins again. This is largely due to reduction in the air temperature of the region. The soil moisture begins to pick up in April being the onset of the raining season and continues to increase till mid-October when it begins to reduce again. The variation in the simulated soil moisture in Fig. 8 is mainly due to the distribution of precipitation in the area.

\section{Forecasted Soil Moisture}

The RCP 8.5 projection was used to forecast soil moisture in the region with the assumption of slow growth income and increased population density (Riahi et al. 2011). The RCP 8.5 projection scenario means that there will be increase in the greenhouse gas emission due to the fact that energy is in high demand in the longterm absence of climate change regulations and policies (Riahi et al. 2011). Fig. 9 


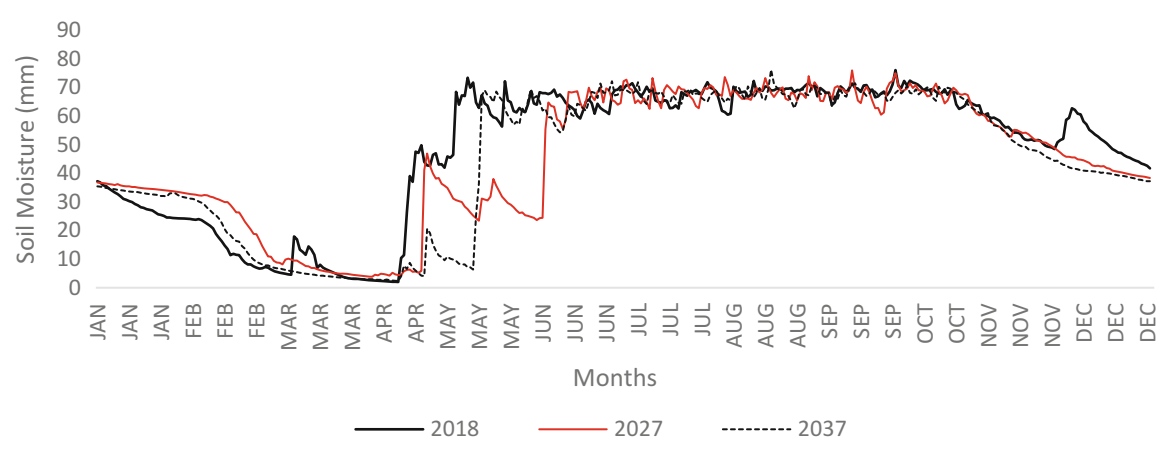

Fig. 10 Seasonal variation of the forecasted soil moisture from January to December for 2018, 2027, and 2037 (Oladapo et al. 2018)

shows the temporal variations of forecasted soil moisture in the sub-basin of the Ogbomoso agricultural watershed in the next 20 years (Oladapo et al. 2018). The forecasted soil moisture showed a general drop in trend which may suggest that there is likely to be a decrease in precipitation and a rise in air temperature in the region within the next 20 years.

Seasonal variation of the SWAT forecasted soil moisture in Fig. 10 which bears similar pattern with that of the simulated soil moisture confirms the key role rainfall plays in the quantity of soil water reserve.

\section{Estimation of Radon Flux Density}

The release of radon gas from the soil can take place either by emanation or through the process of transport. The process whereby a ${ }^{222} \mathrm{Rn}$ atom escapes from ${ }^{226} \mathrm{Ra}$ bearing grains to the pore space in soil is called emanation. The process of radon transport, which occurs in the pore space of the soil, involves the process of advection and diffusion. Diffusion is a product of slope in the radon concentration. Meanwhile, the pressure difference between the ground surface and pore space gives rise to advection. In this chapter, the process of diffusion alone will be considered. This is because influence of most meteorological parameters on the advection can be assumed to be negligible when averaged over one month. Provided that soil under investigation is homogeneous, a one-dimensional diffusion equation can be used to derive the radon flux density from the soil within the region (Goto et al. 2008). There is usually a rise in the radon released into the atmosphere when the soil moisture is low leading to an increase in radon flux density from the soil surface. However, when a certain soil moisture is reached, the radon diffusion and advection process is reduced. This is because the pore space being filled with water slows down the radon flux density from the soil surface (Koarashi et al. 2000; Iimoto 2002). The result of this work is similar to other works on the relationship between soil moisture and radon flux density from the earth surface (Koarashi et al. 2000; Iimoto 2002). The 
radon flux density values estimated in this work will serve as reference since radon flux data are scarce around the world.

The influence of the soil moisture and soil temperature on the radon flux density is considered. The radon flux density, from the soil surface, was estimated using the UNSCEAR radon flux formula (Zhou et al. 2005).

$$
\mathrm{F}=\mathrm{R} \rho_{\mathrm{b}} \varepsilon\left(\frac{T}{273}\right)^{0.75} \sqrt{\lambda D o p \exp \left(-6 S p-6 S^{14 p}\right)}
$$

where $\mathrm{R}$ is the soil ${ }^{226} \mathrm{Ra}$ content $\left(\mathrm{Bq} \mathrm{kg} \_1\right), \rho_{\mathrm{b}}$ is the soil bulk density $\left(\mathrm{kg} \cdot \mathrm{m}^{3}\right), \varepsilon$ is the emanation coefficient of ${ }^{222} \mathrm{Rn}$ in soil, which is a function of the soil temperature ( $\mathrm{T}$, in Kelvin scale) and the water saturation fraction (S), $\lambda$ is the ${ }^{222} \mathrm{Rn}$ decay constant $\left(\mathrm{s}^{-1}\right), p$ is the soil porosity, and $\mathrm{D}_{\mathrm{o}}$ is the ${ }^{222} \mathrm{Rn}$ diffusion coefficient in air $\left(1.1 \times 10^{-5} \mathrm{~m}^{2} \cdot \mathrm{s}^{-1}\right)$. The emanation coefficient $(\varepsilon)$ of ${ }^{222} \mathrm{Rn}$ in soil was estimated from the fitted formula of Zhuo et al. (2005).

The values of the soil moisture and soil temperature simulated by SWAT were inputted into the equation. The evaluation result showed that the UNSCEAR radon flux formula performed well in estimating the radon flux density in the study area when calibrated with observed atmospheric radon concentration in the study area. The values of the estimated radon flux density ranged between 4.03 and 37.30 $\mathrm{mBqm}^{-2} \cdot \mathrm{s}^{-1}$ with a mean of $15.09 \mathrm{mBqm}{ }^{-2} \cdot \mathrm{s}^{-1}$. The overall average radon flux density in the area lies below the world mean value (UNSCEAR 2000). The mean value of radon flux density in the area indicated that Ogbomoso metropolis is not prone to risk of radon exposure and may not cause any health risk such as lung cancer and other respiratory tract diseases. For this reason, it is safe to conclude that the radon flux density will not have any radiological health risk to the inhabitants of Ogbomoso metropolis. However, field measurements of the radon flux density within and outside of Ogbomoso are needed to further verify the reliability of these estimates. Since there exist insufficient radon flux measurements around the globe, these set of estimated radon flux densities in Ogbomos will serve as baseline data for future references. Note that the estimated radon flux densities within Ogbomoso investigated in this chapter are between the soil and the atmosphere, hence the health risk is very negligible. The health effect of radon exhalation within buildings in Ogbomoso which is expected to be higher may, however, pose some radiological health risk. For this reason, it is important to review the health implication of radon exhalation values which are triggered by climate change within Ogbomoso.

\section{Conclusion}

The effects that climate change has on the variation of soil moisture are the focus of this chapter for the purpose of estimating the health effect of radon flux density within Ogbomoso. A 34-year simulation of soil moisture content was executed within Ogbomoso watershed using the hydrological model, Soil Water Assessment 
Tool (SWAT). A 20-year forecast of the soil moisture was also done. The calibrated and validated SWAT model performed well for the simulation of daily soil moisture. A general decline in trend was observed for both the simulated and forecasted soil moisture. This decline in trend may be largely due to rainfall reduction and temperature rising in the region. The SWAT model has proven to be suitable for simulating and forecasting soil moisture in the region. The radon flux density for the study area was estimated using the UNSCEAR radon flux formula. The mean value of the radon flux density of $15.09 \mathrm{mBqm}{ }^{-2} \cdot \mathrm{s}^{-1}$ falls below the estimated world average of $33 \mathrm{mBqm}^{-2} \cdot \mathrm{s}^{-1}$ by UNSCEAR. The result of the estimated radon flux density showed that Ogbomoso region is not prone to high risk of radon exposure to the public. In other words, the estimated radon flux density in the study area will not pose any radiological health risk such as lung cancer or any other respiratory tract diseases to the inhabitant of Ogbomoso metropolis.

Acknowledgments This research is supported by funding from the UK's Department for International Development (DfID) under the Climate Impacts Research Capacity and Leadership Enhancement (CIRCLE) program implemented by the African Academy of Sciences and the Association of Commonwealth University.

\section{References}

Aburnurad KM, Al Tamimi M (2001) Emanation power of radon and its concentration in the soil and rocks. Radiat Meas 34:423

Adabanija MA, Afolabi OA, Olatubosun AT, Kolawole LL (2014) Integrated approach to investigation of occurrence and quality of groundwater in Ogbomoso North, Nigeria. Environ Health Sci 73(1):139-162

AghaKouchak AA (2014) Baseline probabilistic drought forecasting framework using standardized soil moisture index: application to the 2012 United States drought. Hydrol Earth Syst Sci $18: 2485-2492$

Ajibade AC, Rahaman MA, Ogezi AEO (1988) The Precambrian of Nigeria, a geochronological survey. Publication of the Geological Survey of Nigeria, pp 313-324

Alexander L (2011) Climate science: extreme heat rooted in dry soils. Nat Geosci 4:12

Arnold JG, Srinivasan R, Muttiah RS, Williams JR (1998) Large area hydrologic modeling and assessment, Part I: model development. J Am Water Resour Assoc 34(1):73-89

Ball TK, Nicholson RA, Peachey D (1983) Effects of meteorological variables on certain soil gases used to detect buried ore deposits. Trans Inst Min Metall 92:B183-B190

Brookins DG (1990) The indoor radon problem. Columbia University Press, New York, p 229

Broxton, Xubin Zeng, Damien Sulla-Menashe, Peter A. Troch, (2014) A Global Land Cover Climatology Using MODIS Data. J Appl Meteorol Climatol 53 (6):1593-1605

Chen T, De Jeu R, Liu Y, Van der Werf G, Dolman A (2014) Using satellite based soil moisture to quantify the water driven variability in NDVI: a case study over mainland Australia. Remote Sens Environ 140:330-338

Feng H, Liu Y (2015) Combined effects of precipitation and air temperature on soil moisture in different land covers in a humid basin. J Hydrol 531:1129-1140

Fields RW (2010) Climate change and indoor air quality. Contractor report prepared for U.S. Environmental Protection Agency, Office of Radiation and Indoor Air. pp 1-15

Gassman PW, Reyes MR, Green CH, Arnold JG (2007) The Soil and Water Assessment Tool: historical development, applications, and future research directions. Trans ASABE 50(4):12111250 
Goto M, Moriizumi J, Yamazawa H, Iida T, Zhou WH (2008) Estimation of global radon exhalation rate distribution. In: The Natural Radiation Environment. 8th International symposium (NRE VIII). America Institute of Physics, New York, pp 169-171

Gupta ML, Douglass AR, Kawa R, R., Pawson. S. (2004) Use of radon for evaluation of atmospheric transport models: sensitivity to emissions, Tellus Series B. Chem Phys Meteorol 56:404-412

Iida T, Ikebe Y, Suzuki, k., Ueno, k., Wang, Z., Jin, Y. (1996) Continuous measurements of outdoor radon concentrations at various location in East Asia. Environ Int 22(suppl. 1):S139-S147

Iimoto T (2002) Environmental factors varying Rn-220 exhalation rate. In: Proceedings of the Third Workshop in Environmental Radioactivity. Tsukuba, pp 189-194, 5-7 Mar 2002. [in Japanese]

International Commission on Radiological Protection (1993) Protection against Radon-222 at home and at work, vol 23. ICRP Publication 65, Annals of the ICRP. Pergamon Press, Oxford

Koarashi J, Amano H, Iida T (2000) Development of model for water and 222Rn in unsaturated soil. In: Proceedings of the 10th International Congress International Radiation Protection Association, Hiroshima, May 14-19

Koster RD, Dirmeyer PA, Guo Z, Bonan G, Chan E, Cox P, Gordon C, Kanae S, Kowalczyk E, Lawrence D (2004) Regions of strong coupling between soil moisture and precipitation. Science 305:1138-1140

Kritz MA, Ronsner SW, Stockwell DZ (1998) Validation of an off-line three dimensional chemical transport model using observed radon profiles. Int J Geophys Res 103:8425-8430

MacDonald AM, Davies J (2000) A brief review of groundwater for rural water supply in subSaharan Africa. British Geological Survey Technical Report. W.C./00/33. Natural Environmental Research Council, Nottingham, UK. pp 1-24

Mazur D, Janik M et al (1999) Measurements of radon concentration in soil gas by CR-39 detectors. Radiat Meas 31:295

McColl KA, Alemohammad SH, Akbar R, Konings AG, Yueh S, Entekhabi D (2017) The global distribution and dynamics of surface soil moisture. Nat Geosci 10:100

Moriasi DN, Arnold JG, VanLiew MW, Bingner RL, Harem RD, Veith TL (2007) Model evaluation guidelines for systematic quantification of accuracy in watershed simulations, T. ASABE 50:850-900

Neitsch SL, Arnold JG, Kiniry JR, Williams JR (2005) Soil and water assessment tool (SWAT), theoretical documentation. Blackland Research Center, Grassland, Soil and Water Research Laboratory, Agricultural Research Service, Temple

Ohkura T, Yamazawa H, Moriizumi J, Hirao S, Guo Q, Tohjima Y, Iida T (2009) Monitoring network of atmospheric radon-222 concentration and backward trajectory analysis of radon-222 concentration. J Jan Soc Atmos Environ 44(1):42-51. (in Japanese with English abstract)

Oladapo OO, Amekudzi LK, Oni OO, Aremu AA, Osei MA (2018) Simulation and forecasting of soil moisture content variability over Ogbomoso agricultural watershed using the SWAT model. Official conference proceedings of the European conference on sustainability, energy and environment. The Internation Academy Forum. pp 159-173

Ouyang W, Wu Y, Hao Z, Zhang Q, Bu Q, Gao X (2018) Combined impacts of land use and soil property changes on soil erosion in amollisol area under long-term agricultural development. Sci Total Environ 613:798-809

Riahi K, Rao S, Krey V, Cho C, Chirkov V, Fischer G, Kindermann G, Nakicenovic N, Rafaj P (2011) RCP8.5-A scenario of comparatively high greenhouse gas emissions. Climate Change 109:33-57

Santhi C, Arnold JG, Williams JR, Dugas WA, Srinivasan R, Hauck LM (2001) Validation of the SWAT model on a large river basin with point and nonpoint sources. J Am Water Resour Assoc 37:1169-1188

Schery SD, Whittlestone S, Hart KP (1989) The flux of radon and thoron from Australian soils. J Geophys Res 94:8567-8576

Sheffield J, Wood EF (2008) Global trends and variability in soil moisture and drought characteristics, 1950-2000, from observation-driven simulations of the terrestrial hydrologic cycle. J Clim 21:432-458 
Sterling SM, Ducharne A, Polcher J (2013) The impact of global land-cover change on the terrestrial water cycle. Nat Clim Chang 3:385

Tanner AB (1980) Radon migration in the ground: a supplementary review. In: TF Gesell, WM Lowder (eds) Natural radiation environment III, Symposium proceedings, Houston, pp 5-56

United Nation Scientific Committee on the Effects of Atomic Radiation (1993) Sources and effects of ionizing radiation. UNSCEAR 1993 report to general assembly, with scientific annexes, 18. United Nation, New York

United Nation Scientific Committee on the Effects of Atomic Radiation (2000) Sources and effects of ionizing radiation. UNSCEAR 2000 report to general assembly, with scientific annexes, volume I Sources, Annex B. United Nation, New York, pp 115-116

Wanders N, Bierkens MF, deJong SM, deRoo A, Karssenberg D (2014) The benefits of using remotely sensed soil moisture in parameter identification of large-scale hydrological models. Water Resour Res 50:6874-6891

Wang T, Ding AJ, Blake DR, Zahorowski W, Poon N, Li YS (2004) Chemical characterization of the boundary layer outflow of air pollution to Honk Kong during February-April 2001. J Geophys Res 108(D20):8787

Wang Y, Yang J, Chen Y, De Maeyer P, Li Z, Duan W (2018a) Detecting the causal effect of soil moisture on precipitation using convergent cross mapping. Sci Rep 8:12171

Wang Y, Yang J, Chen Y, Wang A, De Maeyer P (2018b) The spatiotemporal response of soil moisture to precipitation and temperature changes in an arid region, China. Remote Sens 10:468

Zahorowski W, Chambers CD, Henderson-Sellers A (2004) Ground based Radon-222 observation and their application to atmospheric studies. J Environ Radioact 76:30-33

Zhang K, Wan H, Zhang M, Wang, b. (2008) Evaluation of the atmospheric transport in a GCM using radon measurements; sensitivity to cumulus convection parameterization. Atmos Chem Phys 8:2311-2832

Zhuo W, Iida T, Furukawa M, Guo Q, Kim YS (2005) Soil radon flux density and outdoor radon concentration in East Asia. Elsevier international congress series, vol 1276, p E-285

Open Access This chapter is licensed under the terms of the Creative Commons Attribution 4.0 International License (http://creativecommons.org/licenses/by/4.0/), which permits use, sharing, adaptation, distribution and reproduction in any medium or format, as long as you give appropriate credit to the original author(s) and the source, provide a link to the Creative Commons license and indicate if changes were made.

The images or other third party material in this chapter are included in the chapter's Creative Commons license, unless indicated otherwise in a credit line to the material. If material is not included in the chapter's Creative Commons license and your intended use is not permitted by statutory regulation or exceeds the permitted use, you will need to obtain permission directly from the copyright holder.

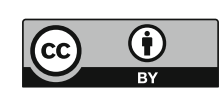

